\section{INHIBITION OF TYROSINE PROTEIN KINASE ACTIVITY BY SYNTHETIC ISOFLAVONES AND FLAVONES}

Sir:

Tyrosine protein kinase is known to be associated with oncogene products of the retroviral $s r c$ gene family ${ }^{1}$. This kinase activity is closely correlated with the ability of retroviruses to transform cells, since mutants of viruses which lack tyrosine kinase activity are defective in malignant transformation ${ }^{22}$. Similar kinase activities are also associated with the cellular receptors for growth factors such as epidermal growth factor $(\mathrm{EGF})^{3)}, \mathrm{PDGF}^{4)}$, insulin ${ }^{5)}$, insulinlike growth factor $I^{(8)}$ and CSF-1 ${ }^{7)}$. It is supposed therefore that tyrosine-phosphorylation plays an important role for diverse cell functions,

Table 1. Effects of isoflavone derivatives on tyrosine protein kinase activity of EGF receptor and growth of RSV-transformed 3Y1 (RSV3Y1) cells.<smiles>O=c1c(-c2ccccc2)coc2ccccc12</smiles>

\begin{tabular}{|c|c|c|c|c|c|c|}
\hline \multirow{2}{*}{ Compound } & \multicolumn{4}{|c|}{ Position } & \multicolumn{2}{|c|}{$\mathrm{IC}_{50}(\mu \mathrm{g} / \mathrm{ml})$} \\
\hline & 2 & 5 & 7 & $4^{\prime}$ & PKI ${ }^{\mathrm{a}}$ & RSV3Y1 \\
\hline $\begin{array}{l}\text { PKI-1 } \\
\text { (Genistein) }\end{array}$ & - & $\mathrm{OH}$ & $\mathrm{OH}$ & $\mathrm{OH}$ & 0.7 & 7.0 \\
\hline PKI-2 & $\mathrm{CH}_{3}$ & $\mathrm{OH}$ & $\mathrm{OH}$ & $\mathrm{OH}$ & 2.0 & 25.0 \\
\hline PKI-3 & $\mathrm{CH}_{3}$ & $\mathrm{OH}$ & $\mathrm{OH}$ & $\mathrm{OCH}_{3}$ & 11.0 & 15.0 \\
\hline PKI-4 & $\mathrm{CH}_{3}$ & OAc & OAc & $\mathrm{OCH}_{3}$ & $>100$ & 40.0 \\
\hline PKI-5 & $\mathrm{COOH}$ & $\mathrm{OH}$ & $\mathrm{OH}$ & $\mathrm{OCH}_{3}$ & 10.0 & $>100$ \\
\hline PKI-6 & $\mathrm{COOC}_{2} \mathrm{H}_{5}$ & $\mathrm{OH}$ & $\mathrm{OH}$ & $\mathrm{OCOCOOC}_{2} \mathrm{H}_{5}$ & 1.0 & $>100$ \\
\hline PKI-7 & $\mathrm{COOH}$ & $\mathrm{OH}$ & $\mathrm{OH}$ & $\mathrm{OH}$ & 2.0 & $>100$ \\
\hline PKI-8 & $\mathrm{CH}_{2} \mathrm{~N}<\underset{\mathrm{CH}_{3}}{\mathrm{CH}_{3}}$ & $\mathrm{OH}$ & $\mathrm{OH}$ & $\mathrm{OCH}_{3}$ & $>100$ & 18.0 \\
\hline PKI-9 & $\mathrm{CH}_{2} \mathrm{NH}-$ & $\mathrm{OH}$ & $\mathrm{OH}$ & $\mathrm{OCH}_{3}$ & $>100$ & 16.0 \\
\hline PKI-10 & $\mathrm{CH}_{2} \mathrm{NHCH}_{2} \mathrm{CH}_{2} \mathrm{OH}$ & $\mathrm{OH}$ & $\mathrm{OH}$ & $\mathrm{OCH}_{3}$ & $>100$ & $>100$ \\
\hline PKI-11 & $\mathrm{CH}_{2}{ }^{\prime}$ & $\mathrm{OH}$ & $\mathrm{OH}$ & $\mathrm{OH}$ & 10.0 & 9.5 \\
\hline PKI-12 & $\mathrm{COOC}_{2} \mathrm{H}_{5}$ & $\mathrm{OH}$ & $\mathrm{OH}$ & $\mathrm{OH}$ & 2.0 & 50.0 \\
\hline PKI-13 & $\mathrm{CONH}_{2}$ & $\mathrm{OH}$ & $\mathrm{OH}$ & $\mathrm{OH}$ & 10.0 & $>100$ \\
\hline PKI-14 & $\mathrm{CONHCH}_{3}$ & $\mathrm{OH}$ & $\mathrm{OH}$ & $\mathrm{OH}$ & 15.0 & $>100$ \\
\hline PKI-15 & $\mathrm{CONHCH}_{2} \mathrm{CH}_{2} \mathrm{OH}$ & $\mathrm{OH}$ & $\mathrm{OH}$ & $\mathrm{OH}$ & 15.0 & $>100$ \\
\hline PKI-16 & $\mathrm{CH}_{2} \mathrm{SCH}_{3}$ & $\mathrm{OH}$ & $\mathrm{OH}$ & $\mathrm{OH}$ & 5.0 & 20.0 \\
\hline PKI-17 & $\mathrm{CH}_{2} \mathrm{~S}-$ & $\mathrm{OH}$ & $\mathrm{OH}$ & $\mathrm{OH}$ & 5.0 & 20.0 \\
\hline PKI-18 & $\mathrm{CH}_{2} \mathrm{SCH}_{2} \mathrm{CH}_{2} \mathrm{COOH}$ & $\mathrm{OH}$ & $\mathrm{OH}$ & $\mathrm{OH}$ & 10.0 & 90.0 \\
\hline PKI-19 & $\mathrm{COOCH}_{3}$ & $\mathrm{OH}$ & $\mathrm{OH}$ & $\mathrm{OH}$ & 2.0 & 60.0 \\
\hline PKI-20 & $\mathrm{COOCH}<\mathrm{CH}_{3}$ & $\mathrm{OH}$ & $\mathrm{OH}$ & $\mathrm{OH}$ & 10.0 & 25.0 \\
\hline PKI-21 & $\mathrm{COOCH}_{2} \mathrm{CH}_{2} \mathrm{OCH}_{3}$ & $\mathrm{OH}$ & $\mathrm{OH}$ & $\mathrm{OH}$ & 6.0 & 60.0 \\
\hline PKI-22 & $\mathrm{CH}_{2} \mathrm{SCH}_{2} \mathrm{COOC}_{2} \mathrm{H}_{5}$ & $\mathrm{OH}$ & $\mathrm{OH}$ & $\mathrm{OH}$ & 4.0 & $>100$ \\
\hline PKI-23 & $\begin{array}{c}\mathrm{CH}_{2} \mathrm{SCH}_{2} \mathrm{CHCH}_{2} \mathrm{OH} \\
\text { OH }\end{array}$ & $\mathrm{OH}$ & $\mathrm{OH}$ & $\mathrm{OH}$ & 4.0 & $>100$ \\
\hline PKI-24 & $\mathrm{CH}_{2} \mathrm{~N}-$ & $\mathrm{OH}$ & $\mathrm{OH}$ & $\mathrm{OH}$ & 15.0 & $>100$ \\
\hline
\end{tabular}

a Protein kinase inhibition. 
cellular differentiation and malignant transformation. From this point of view, a specific inhibitor for tyrosine protein kinase is expected to be a good tool for understanding the physiological role of tyrosine-phosphorylation of the various functional cellular proteins. In this line of screening, we isolated genistein, an isoflavone, from fermentation broth of a Pseudomonas species $^{8)}$. We report here the inhibitory effect of isoflavones and flavones on tyrosine protein kinase activity and growth of Rous sarcoma virus(RSV)-transformed cells.

Isoflavone derivatives (PKI-1 to PKI-24) were synthesized in our laboratories and listed in Table 1. Acacetin, prunetin and daidzein were purchased from Laboratories Sarget. Biochanin A was obtained from Aldrich Chemical Co.; flavone, kaempferol and apigenin from Sigma Chemical Company and quercetin from Nakarai
Chemicals, Ltd.

Protein kinase activity of EGF receptor was determined as follows. The kinase reaction were performed in a solution containing PIPES-NaOH $20 \mathrm{~mm}$, pH 7.2, $\mathrm{MgCl}_{2} 10 \mathrm{~mm}$, $\mathrm{MnCl}_{2} 3 \mathrm{mM}$, dithiothreitol $1 \mathrm{mM}$, sodium vanadate $100 \mu \mathrm{M},\left[\gamma^{-32} \mathrm{P}\right] \mathrm{ATP}(4 \mathrm{mCi} / \mu \mathrm{mol}) 10 \mu \mathrm{M}$, mouse EGF (Collaborative Research) $1 \mu \mathrm{g} / \mathrm{ml}$, A431 cell membrane $10 \mu \mathrm{g}$, which was prepared as described previously ${ }^{8)}$, and the inhibitor. The reaction was continued for 5 minutes at $0^{\circ} \mathrm{C}$ and terminated by addition of LAEMMLI's SDS sample buffer ${ }^{103}$ and boiling for 2 minutes. The samples were analyzed by SDS-polyacrylamide gel electrophoresis followed by autoradiography. The bands of the EGF receptor were excised from the gels and the radioactivity was counted with a liquid scintillation counter. The inhibitory activity was calculated from the re-

Table 2. Effect of flavonoids on tyrosine protein kinase activity of EGF receptor.<smiles>O=C1c2ccccc2OCC1c1ccccc1</smiles>

\begin{tabular}{|c|c|c|c|c|c|c|c|}
\hline \multirow{2}{*}{ Compound } & \multicolumn{5}{|c|}{ Position } & \multicolumn{2}{|c|}{$\mathrm{IC}_{50}(\mu \mathrm{g} / \mathrm{ml})$} \\
\hline & 2 & 5 & 7 & $3^{\prime}$ & $4^{\prime}$ & $\mathrm{PKI}^{2}$ & RSV3Y1 \\
\hline Genistein & - & $\mathrm{OH}$ & $\mathrm{OH}$ & - & $\mathrm{OH}$ & 0.7 & 7.0 \\
\hline Prunetin & - & $\mathrm{OH}$ & $\mathrm{OCH}_{3}$ & 一 & $\mathrm{OH}$ & 4.2 & 25.0 \\
\hline Daidzein & - & - & $\mathrm{OH}$ & - & $\mathrm{OH}$ & $>100$ & 25.0 \\
\hline Biochanin A & - & $\mathrm{OH}$. & $\mathrm{OH}$ & - & $\mathrm{OCH}_{3}$ & 26.0 & 18.0 \\
\hline Genistin & - & $\mathrm{OH}$ & Glucose & - & $\mathrm{OH}$ & $>100$ & $>100$ \\
\hline
\end{tabular}<smiles>O=c1cc(-c2ccccc2)oc2ccccc12</smiles>

\begin{tabular}{lcccccccr}
\hline \multirow{2}{*}{ Compound } & \multicolumn{9}{c}{ Position } & & \multicolumn{2}{c}{$\mathrm{IC}_{50}(\mu \mathrm{g} / \mathrm{ml})$} \\
\cline { 2 - 4 } \cline { 8 - 9 } & 3 & 5 & 7 & $3^{\prime}$ & $4^{\prime}$ & & PKI $^{a}$ & RSV3Y1 \\
\hline Apigenin & - & OH & OH & - & OH & & 25.0 & 11.0 \\
Acacetin & - & OH & OH & - & $\mathrm{OCH}_{3}$ & & 40.0 & 24.0 \\
Flavone & - & - & - & - & - & & 50.0 & 7.0 \\
Kaempferol & $\mathrm{OH}$ & $\mathrm{OH}$ & $\mathrm{OH}$ & - & $\mathrm{OH}$ & & 3.2 & 14.0 \\
Quercetin & $\mathrm{OH}$ & $\mathrm{OH}$ & $\mathrm{OH}$ & $\mathrm{OH}$ & $\mathrm{OH}$ & & 5.0 & 12.0 \\
\hline
\end{tabular}

a Protein kinase inhibition. 
maining protein kinase activity. Cytotoxic activity was assayed using RSV-transformed $3 \mathrm{Y} 1$ (RSV3Y1) cells. RSV3Y1 cells were cultured in DulBecco's modified EAGLE's medium (DMEM) supplemented with $7 \%$ foetal bovine serum (Gibco) with or without an inhibitor. After 48 hours, the viable cells were counted by trypan blue exclusion.

In order to clarify the structure-activity relationship, the inhibitory activity of flavonoids was investigated against tyrosine kinase. Prunetin, kaempferol and quercetin exhibited high inhibitory activity (Table 2). The inhibitory activity decreased drastically either by the removal of a hydroxyl group from 5 position (flavone and daidzein) or by the addition of a methoxy group to $4^{\prime}$ position (biochanin $\mathrm{A}$ and acacetin). Addition of a methoxy group at 7 position (prunetin) also reduced the inhibitory activity. Especially a bulky group at 7 position such as $O$-glucose (genistin) completely abolished the activity. These results indicate that a hydroxyl group at 5 position is essential for inhibitory activity and that at 7 and $4^{\prime}$ positions is necessary for full expression of the activity. Although quercetin was highly active against tyrosine kinase, it also inhibited other enzymes such as cAMP-dependent protein kinase ${ }^{11)}$, protein kinase $\mathrm{C}^{12}$, phosphorylase kinase ${ }^{13)}$, $\mathrm{Na}^{+}, \mathrm{K}^{+}$-ATPase ${ }^{14)}$ and $5^{\prime}$-nucleotidase (AKIYAMA and OGaWARA; unpublished result).

From the results described above, several isoflavones with the modification at 2 position were synthesized and tested for their activity. As shown in Table 1, the half maximum effect $\left(\mathrm{IC}_{50}\right)$ was observed at the range of $0.7 \mu \mathrm{g} / \mathrm{ml}$ of PKI-1 (genistein) to more than $100 \mu \mathrm{g} / \mathrm{ml}$ of PKI-4, PKI-8, PKI-9 and PKI-10. Among these compounds, PKI-2, PKI-6, PKI-7, PKI-12, PKI-19, PKI-22 and PKI-23 showed a considerably higher inhibitory activity, but genistein was the strongest. PKI-4, PKI-8, PKI-9 and PKI-10 showed $\mathrm{IC}_{50}$ at more than $100 \mu \mathrm{g} / \mathrm{ml}$. As described previously ${ }^{15)}$, genistein scarcely inhibited serine/threonine protein kinases such as cAMP-dependent protein kinase, protein kinase $C$ and phosphorylase kinase at $100 \mu \mathrm{g} / \mathrm{ml}$. PKI-6, PKI-7 and PKI-23 exhibited similar properties. Thus, the inhibitory activity of these compounds were highly specific for tyrosine protein kinases.

Next, we examined the cytotoxic effect of isoflavones on RSV3Y1 cells (Table 1). $\mathrm{IC}_{50}$ values of PKI-6, PKI-7, PKI-22 and PKI-23 against the growth of RSV-transformed cells were over $100 \mu \mathrm{g} / \mathrm{ml}$, although they showed a considerably high inhibitory activity against tyrosine protein kinase. Therefore, no close correlation was observed between the inhibitory activity against tyrosine kinase and the inhibition of cell proliferation. Similar results were also obtained with flavonoids (Table 2). All the flavonoids examined exhibited a fair inhibitory activity on proliferation of RSV3Y1 cells, although some compounds such as daidzein and flavone showed a poor inhibitory effect on tyrosine kinase.

\section{Acknowledgment}

This work was supported in part by the Grantin-Aid for cancer research from the Ministry of Education, Science and Culture of Japan and Suzuken Foundation.

\section{Hiroshi Ogawara}

Department of Biochemistry, Meiji College of Pharmacy, 1-35-23 Nozawa, Setagaya-ku, Tokyo 154, Japan

\section{Tetsu AkIYama}

Department of Pathology, Institute for Virus Research, Kyoto University, Kawahara-machi, Shogo-in, Sakyo-ku, Kyoto 602, Japan

\section{ShuN-IChI Watanabe NoRIKI ITO MASATO KOBORI Yoshiko SEODA}

Central Research Institute, Yamanouchi Pharmaceutical Co., Ltd., 1-1-8 Azusawa, Itabashi-ku, Tokyo 174, Japan

(Received September 8, 1988)

\section{References}

1) Hunter, T. \& J. A. Cooper: Protein tyrosine kinases. Annu. Rev. Biochem. 54: 897 930, 1985

2) Bishop, J. M.: Cellular oncogenes and retro- 
viruses. Annu. Rev. Biochem. 52: $301 \sim 354$, 1983

3) Ushiro, H. \& S. CoHEN: Identification of phosphotyrosine as a product of epidermal growth factor-activated protein kinase in A-431 cell membranes. J. Biol. Chem. 255: 8363 8365,1980

4) Ek, B.; B. Westermark, A. Wasteson \& C.-H. Heldin: Stimulation of tyrosine-specific phosphorylation by platelet-derived growth factor. Nature 295: 41.9 420, 1982

5) Kasuga, K.; Y. Zick, D.L. Blithe, M. Crettaz \& C. R. KAHN: Insulin stimulates tyrosine phosphorylation of the insulin receptor in a cell-free system. Nature 298: 667 669, 1982

6) JaCoBs, D.; F. C. KulL, Jr., H. S. EARP, M. E. Svoboda, J. J. Van WyK \& P. Cuatrecasas: Somatomedin-C stimulates the phosphorylation of the beta-subunit of its own receptor. J. Biol. Chem. 258: 9581 9584, 1983

7) Sherr, C. J.; C. W. Rettenmier, R. SACCA, M. F. Roussel, A. T. Look \& A. R. Stanley: The c-fms proto-oncogene product is related to the receptor for the mononuclear phagocyte growth factor, CSF-1. Cell 41: 665 676, 1985

8) Ogawara, H.; T. Akiyama, J. Ishida, S. WataNABE \& K. SUZUKI: A specific inhibitor for tyrosine protein kinase from Pseudomonas. J. Antibiotics 39: 606 608, 1986

9) Axryama, T.; T. Kadooka \& H. Ogawara: Purification of the epidermal growth factor receptor by tyrosine-Sepharose affinity chromato- graphy. Biochem. Biophys. Res. Commun. 131: $442 \sim 448,1985$

10) LAEMMLI, U. K.: Cleavage of structural proteins during the assembly of the head of bacteriophage T4. Nature 227: 680 685, 1970

11) Graziani, Y.; R. Chayoth, N. Karny, B. Feldman \& J. LeVY: Regulation of protein kinases activity by quercetin in Ehrlich ascites tumor cells. Biochim. Biophys. Acta 714: 415 421, 1981

12) Gschwendt, M.; F. Horn, W. Kittstein, G. Furstenberger, E. BAsemfelder \& F. MARKs: Calcium and phospholipid-dependent protein kinase activity in mouse epidermis cytosol. Stimulation by complete and incomplete tumor promoters and inhibition by various compounds. Biochem. Biophys. Res. Commun. 124: 63 68, 1984

13) SRIVASTAVA, A.K.: Inhibition of phosphorylase kinase, and tyrosine protein kinase activities by quercetin. Biochem. Biophys. Res. Commun. 131: $1 \sim 5,1985$

14) LANG, D. R. \& E. RACKER: Effects of quercetin and $F_{1}$ inhibitor on mitochondrial ATPase and energy-linked reactions in submitochondrial particles. Biochim. Biophys. Acta 333: 180 186,1974

15) AkiYama, T.; J. Ishida, S. Nakagawa, H. Ogawara, S. Watanabe, N. Itoh, M. ShibuYA \& $Y$. FUKAMI: Genistein, a specific inhibitor of tyrosine protein kinases. J. Biol. Chem. 262: 5592 5595, 1987 